\title{
THE RELATIONSHIP BETWEEN HIGH PERFORMANCE WORK SYSTEMS AND EMPLOYEE PROACTIVE BEHAVIOUR: ROLE BREADTH SELF- EFFICACY AND FLEXIBLE ROLE ORIENTATION AS MEDIATING MECHANISMS
}

\begin{abstract}
Drawing on the contextual perspective (Johns, 2006), this study provides novel empirical evidence on how the organisational context (specifically, the firm's human resource strategy) has an effect on employee proactivity. We use matched data from managers and employees in 102 Spanish professional service firms to examine how high performance work systems contribute to enhance employee proactive behaviours through two motivational variables: role breadth self-efficacy and flexible role orientation (Parker, 2000). Results of a multilevel study demonstrate that role breadth self-efficacy mediates between HPWS and employee proactivity, but flexible role orientation does not mediate this relationship.
\end{abstract}

Keywords: HPWS, proactive behaviours, role breadth self-efficacy, flexible role orientation, multilevel. 


\section{INTRODUCTION}

Proactive behaviour "is about taking control to make things happen rather than watching things happen" (Parker et al., 2010: 828). It refers to employee behaviours that are self-starting, change oriented, and future focused. As work becomes more decentralised and pressures for innovation increase, proactive behaviour takes on an increasingly critical role in organisational success (Crant, 2000; Thomas et al., 2010). Previous research has shown that employee proactive behaviours positively contribute to individual outcomes, such as employee creativity, task performance and career initiative (e.g. Seibert et al., 2001; Hermann and Felfe, 2014). They are also beneficial for organisational innovation and success (e.g. Kickul and Gundry, 2002), since they induce individuals to study their environments thoroughly and help them to anticipate potential problems (Thomas et al., 2010).

Given the benefits of proactive behaviour, identifying its antecedents has become a critical issue in the literature (Maden, 2015). There is now a body of research analysing the influence of individual characteristics such as intrinsic motivation, goal orientation or organisational tenure on proactivity (see, for example, Frese and Fay, 2001; Sonnentag, 2003; Belschak and Den Hartog, 2010). However, few studies have analysed the role of contextual variables of the organisation as enablers of employee proactive behaviour (Batistič et al., 2016). This is surprising since the contextual perspective (Johns, 2006) has revealed how situational opportunities and constraints at the firm level play a key role in promoting or hindering relevant employee behaviours.

From the contextual perspective, organisational context can be viewed as a large set of constraints and opportunities (sometimes countervailing one another) that gives meaning to the occurrence (or lack of occurrence) of organisational behaviour (Johns, 
1991). The large number of facets that make up the organisational context, some of which promote specific proactive behaviours while others hinder them, makes it difficult to study the contextual influences on proactive behaviours unless a broad and systematic description and measurement of the relevant contextual variables is adopted (Johns, 2006). We focus on HR practices as relevant contextual variables that may influence proactive behaviour (Crant, 2000; Maden, 2015). These practices contribute to delineate the roles in the organisation, shape the pattern of interactions between and among managers and employees (MacDuffie, 1995) and create and support individual employee behaviours and competences (Gratton et al., 1999). For instance, the extant empirical evidence has demonstrated that HR practices related to job design, in particular higher autonomy and job complexity, contribute to proactivity (Axtell and Parker, 2003; Parker et al., 2006).

Despite the relevance of HR practices in fostering desired behaviours among employees in the firm further research is still needed to improve insights on what managers can do to delineate a HR strategy that enhances the proactivity of their workforce. This paper contributes to analysis on the influence of HR practices on proactivity in two ways. First, as Parker (2000) highlights, there is a need to examine the joint influence of a set of HR practices on proactivity. Our study focuses particularly on how high performance work systems (HPWS) influence employee proactivity. The focus on HPWS (as a set of interconnected HR practices) rather than on isolated HR practices allows us to capture the complementarities and contradictions among the HPWS components, under the premise that a HPWS practice may be more effective at stimulating the desired employee behaviour when it is implemented in concert with other HPWS practices (Ichniowski et al., 1997; Johns, 1991, 2006). It also gives us a better 
understanding of the variety of mechanisms through which the opportunities and constraints in the organisational context influence individual proactive behaviour.

Second, our study examines the mechanisms through which the HPWS-proactive behaviour relationship occurs. Parker (2000) suggested that the influence of contextual variables on employee proactive behaviour is mediated by employees' psychological states. This model differs from other theoretical frameworks which considered that individual and organisational variables directly influence proactivity (e.g., Crant, 2000). When deciding on which potential mediating mechanisms to consider, it should be taken into account that proactive behaviours are motivation-driven. As a result, several authors (e.g. Arefin et al., 2015; Caesens et al., 2016) have suggested that motivational variables should be considered in order to understand why HR practices promote proactivity. Following the suggestions by Parker and colleagues we will consider two motivational variables to explain the influence of HPWS on employee proactive behaviour, namely, role breadth self-efficacy (RBSE) - employees' confidence in their ability to successfully fulfil broad roles, and flexible role orientation (FRO) - employees' engagement in broad, open-ended and interdependent roles (Parker et al., 1997; Parker 1998, 2000).

To address these questions, our study takes a multilevel perspective to explain how far the context in which behaviour occurs affect employees' proactive behaviours (Johns, 2006; Hitt et al., 2007). We propose a specific type of multilevel model - a crosslevel model (Preacher et al. 2010) - because our focal units (organisation and employees) belong to different levels of analysis (Hitt et al., 2007): the independent variable (HPWS) is an organisational construct and the dependent (proactive behaviour) and mediating variables (RBSE and FRO) are individual (employee-level) constructs. This is consistent 
with the meso theory's premise that organisations affect individual attitudes and behaviours (House et al., 1995).

Our study focuses on professional service firms (PSFs). The PSF context is a particularly attractive field for researchers with an interest in human resource management (Richter et al., 2008). This context is also suitable for exploring employee proactive behaviours given the decentralised structures of PSFs (Kipping and Kirkpatrick, 2013), the need to constantly introduce innovations in the services provided to customers (Lowendahl, 2005) and the increasing competition among firms (Hitt et al., 2006).

The paper is structured as follows. First we introduce HPWS as organisational antecedents of proactivity. We then examine how RBSE and FRO mediate the relationship between HPWS and employee proactive behaviour. After the theoretical review, we present our methodology and results, and discuss the main conclusions, implications and limitations of the research.

\section{HPWS AS ANTECEDENTS OF EMPLOYEE PROACTIVE BEHAVIOUR}

As mentioned above, proactive behaviour refers to self-initiated and futureoriented action that aims to change and improve the situation or oneself (Parker et al., $2006 ; 2010)$. It implies taking the initiative at work to challenge the status quo rather than adapting to the conditions (Crant, 2000: 436). Proactive behaviour may be improved through the organisational context, and in particular through HR practices (Johns, 2006; Parker et al., 2010). High performance work systems (HPWS) consist of an interconnected set of HR practices posited on promoting workforce ability, motivation and opportunity to perform behaviours consistent with organisational goals (Jiang et al., 
2012a). Previous studies have proposed the existence of a relationship between HPWS and proactive behaviour based on different theoretical perspectives. Some of these studies explain the HPWS-proactive behaviour relationship in terms of image defence and enhancement motives (Leary and Kowalski, 1990); other studies use the norm of reciprocity to explain why employees perceiving organisational support feel obligated to reciprocate by being proactive (Blau, 1964; Eisenberger et al., 1986); other studies base their explanations on employees' uncertainty reduction motivation (Elliot and Devine, 1994). Finally, a widespread perspective to analyse the complex relationship between HPWS and proactive behaviour is the Ability, Motivation and Opportunity to participate (AMO) model (Bailey et al., 2001; Subramony, 2009; Gardner et al., 2011). We draw on the completeness of this framework to explain how HPWS practices aimed at increasing employee motivation, abilities and opportunity to perform to increase employee proactive behaviour.

HPWS are designed to ensure that employees have a broad range of superior knowledge, skills and abilities (KSAs), both by directly fostering employees' human capital (e.g. through recruitment and training practices), and by helping to attract capable employees (for instance, by promoting practices such as competitive compensation) (Way, 2002; Snape and Redman, 2010). Proactive behaviours depend on employee cognitive ability; in other words these behaviours can be developed better if employees are good at their work, and are able to learn quickly (Frese and Fay, 2001). As HPWS contribute to developing KSAs, employees assume that they can actually do something about improving work and effectiveness, thus increasing the likelihood of their engaging in proactive behaviours (Frese and Fay, 2001). 
Additionally, HPWS practices also encourage the belief among employees that greater effort at work will lead to higher rewards, therefore fostering their motivation (Jiang et al., 2012a). Because proactive behaviours require additional effort on the part of the employee, motivational initiatives are needed to trigger proactive behaviour and to persist with it (Frese et al., 1997). There is some evidence for the influence of motivationenhancing HR practices on proactive behaviour. For instance, Crawshaw et al. (2012) demonstrate that career development opportunities in the firm are significantly related to higher employee proactivity.

Finally, HPWS include initiatives to give employees greater participation and control at work (Subramony, 2009; Jiang et al., 2012a). With higher control at work, employees tend to expect that future job situations will also be controllable thus increasing their willingness to behave proactively (Frese and Fay, 2001; Unsworth and Parker, 2003). Several studies demonstrate that control at work and autonomy influence proactive behaviours (Frese et al., 1996; Speier and Frese, 1997; Ohly et al., 2006; Parker et al., 2006; Shin and Kim, 2015).

Some recent studies have provided further evidence of the relationship between HPWS and employee proactivity by assuming that the different HPWS practices may have a joint effect on proactivity. This is the case of Maden (2015), who demonstrates the relevance of empowerment, competence development and fair reward HR practices on employee proactive behaviour, and Arefin et al. (2015), who find that HPWS, as a whole, have a positive relationship with employee proactive behaviour. Despite these results, more work is needed to understand the processes through which HPWS affect employee proactive behaviour (Maden, 2015). In the next section, we will focus on the motivational paths that may help us to understand this relationship. 


\section{THE MEDIATING EFFECT OF ROLE BREADTH SELF-EFFICACY AND FLEXIBLE ROLE ORIENTATION IN THE HPWS-PROACTIVE BEHAVIOUR RELATIONSHIP}

According to Parker et al. (2010), researchers should focus on motivational variables to understand how context promotes proactive behaviour in the firm. These authors suggest that contextual variables shape individuals' motivational states which, in turn, influence proactive behaviours. They specifically highlight proactive motivational states, which unlike other employee-outcome variables (e.g. organisational commitment, job satisfaction) are active in their orientation and emphasise the direction of employees' efforts in the organisation. Proactive motivational states imply that employees are spurred to act on the environment in a self-directed way to produce changes (Parker, 2000).

Two proactive motivational states are relevant in the analysis of proactive behaviour, namely, role breadth self-efficacy (RBSE) and flexible role orientation (FRO). In Parker's (2000: 462) words, considering RBSE and FRO in studies about proactive behaviour "should help to close the gap between the much talked about proactive workforce and the lack of systematic inquiry on how to promote this type of employee". While FRO concerns employees' view of their roles and responsibilities, RBSE refers to employees' judgement about their capabilities to carry out a range of integrative and interpersonal tasks (Parker, 2000). In this sub-section we analyse the mediating effect of RBSE and FRO in the relationship between HPWS and proactive behaviour.

Role breadth self-efficacy. In general terms, self-efficacy refers to an person's judgement about his or her ability to perform specific tasks (Bandura, 1986). Drawing 
from Bandura's studies, Parker (1998: 835) developed this concept further and proposed the concept of role breadth self-efficacy (RBSE) defined it as "the extent to which people feel confident that they are able to carry out a broader and more proactive role, beyond traditional prescribed technical requirements."

Several authors highlight the relevance of RBSE in promoting employee proactive behaviour because employees need to be confident that they can be proactive and overcome obstacles (Strauss et al., 2009; Parker et al., 2010; Martin et al., 2013; Hwang et al., 2015). According to Parker et al. (2010: 834), a belief that one can be successful at work is likely to be relevant in proactive behaviours because such behaviours entail a high potential psychological risk to the individual (e.g. proactive employees may have to deal with others' resistance and scepticism) (Parker et al., 2010). RBSE gives employees the confidence they need to cope with the consequences of proactivity. Several researchers have shown empirically that RBSE is a predictor of proactive behaviour. For instance, Axtell et al. (2000) demonstrate that RBSE is one of the strongest individual determinants of employees' tendency to suggest ideas that help improve the way things are done. Parker et al. (2006) corroborate that RBSE significantly influences proactive idea implementation and proactive problem solving among employees. Strauss et al. (2009) confirm RBSE as an antecedent of proactivity directed towards the team and the organisation. Similarly, Ohly and Fritz (2007) find evidence that RBSE contributes to a general measure of proactive behaviour.

An interesting feature of RBSE is that firms can use a range of interventions, particularly HR practices, to promote it among their employees (Parker, 1998). The

\footnotetext{
${ }^{1}$ In the proactive behaviour literature RBSE is preferred to the general term self-efficacy because RBSE refers to a similar level of generality as proactive behaviour, both of which include a broad range of work-related behaviours (Sonnentag and Spychala, 2012).
} 
theoretical foundation of this approach is rooted in Bandura's (1986) idea of enactive mastery, defined as repeated performance accomplishments. By enhancing the set of KSAs the employee possesses, HPWS reinforce the perceived mastery of the assigned tasks, thereby boosting employee confidence in a range of proactive behaviours (Wood and Bandura, 1989; Frese and Fay, 2001). HPWS can also contribute to enhance employee RBSE through motivation-oriented practices that act persuasively to reinforce a feeling of competence and belonging to the organisation (Parker, 1998). Finally, HPWS help to expand the boundaries of previously narrow jobs by giving employees greater influence in workplace decisions and performing activities they would not normally do, such as solving problems and making improvements (Axtell and Parker, 2003). These initatives help people to feel capable of taking responsibility for a set of tasks beyond their job requirements (Parker, 1998) and facilitate employee understanding of the boundaries of the extended role in which to develop their mastery (Conger and Kanungo, 1988). Consistent with the above discussion, we formulate our first hypothesis as follows:

H1: RBSE mediates the relationship between HPWS and employees' proactive behaviour

Flexible role orientation. Broadly speaking, employee role orientation refers to what employees regard as the boundaries of their role in the organisation; that is, their beliefs about the breadth of tasks, goals, and problems they see as being part of their responsibilities (Parker et al., 1997; Parker, 2007). Employees with a flexible role orientation believe that their roles in the firm are far-reaching, and consequently feel ownership of the goals and problems beyond their immediate set of tasks (Campbell, 2000). FRO implies that "individuals define their job in proactive rather than passive terms, such as by perceiving it as their responsibility to anticipate and prevent problems, 
rather than only react to problems" (Parker, 2007: 407). In other words, FRO implies a move away from a narrow “that's not my job” mentality (Unsworth and Parker, 2003).

FRO is expected to contribute to employee proactive behaviour. Parker (2007) provides two explanations for this relationship based on the role-identity and the goal setting theories, respectively. First, the role-identity theory (Morrison, 1994) suggests that employees direct their efforts towards specific behaviours depending on their role definition. An employee's motivation to show a given behaviour is higher when he or she considers that behaviour to be part of his or her role. This idea is related to the self-concept component of roles, as defined by Neale and Griffin (2006), who state that individuals prefer to exhibit behaviours that are self-congruent. Drawing from these ideas, employees are more likely to engage in proactive behaviours when they define these behaviours as part of their roles. Second, from the goal setting theory (Locke and Latham, 1990) employees' goals guide their behaviours. Employees with a FRO feel ownership of innovative and creative goals beyond their narrow job and are therefore more likely to focus their efforts on achieving those goals than employees who do not consider these goals as part of their job. There is some empirical evidence for the positive relationship between FRO and proactive behaviour. For instance, Howell and Boies (2004) demonstrate that FRO predicts idea generation, and Axtell et al. (2000) find it has a positive effect on the likelihood of employees making innovative suggestions. Parker et al. (2006) also demonstrate that employees with more FRO tend to show a more proactive approach to problem solving and more proactive idea implementation.

Because FRO refers to employees' beliefs about their role, it can be altered in response to change in the external conditions (Parker, 2007). HPWS may contribute to promote employee FRO in different ways. Through skill-enhancing practices, HPWS 
contribute to employees' FRO by fostering a climate of personal growth among the workforce. Due to the rapid process of knowledge obsolescence in dynamic environments, the importance of being "ahead on the learning curve" is crucial in creating employees with broad roles in the organisation (Dyer and Shafer, 2002). Motivationenhancing HR practices may also contribute to enhance employees' FRO by generating a more positive view of the exchange between the employee and the organisation and promoting a higher level of confidence between them (Guest and Conway, 2002). Employees who perceive that the firm treats them fairly will be more willing to adjust to potential adversities that may appear as a result of their broader role. Finally, by giving employees the opportunity to participate in the firm with ideas or suggestions, HPWS encourage people's psychological ownership (i.e. a feeling of ownership of workplace problems) that contributes to FRO (Shukla and Singh, 2014). According to this reasoning, we expect that:

H2: FRO mediates the relationship between HPWS and employees' proactive behaviour

\section{METHOD}

\section{Sample}

The fieldwork for this study was conducted on a sample of Spanish professional service firms (PSFs). To select the sample, we followed Malhotra and Morris (2009) in recognising differences in the nature of knowledge, jurisdictional control, and type of client relationships among three sub-sectors of the professional service sector, namely, law, accounting, and engineering consulting, which made up the population for our study. The population of firms $(\mathrm{n}=10290)$ was selected from the SABI Database (Sistema de 
Análisis de Balances Ibéricos), according to the following NACE-Rev.1 2009 industrial classification codes: 6910 (legal activities), 6920 (accounting, bookkeeping and auditing activities; tax consultancy), and 7112 (engineering activities and related technical consultancy), and the number of employees (between 5 and 250 employees). We invited 300 companies to participate in the study, selected randomly from the population of Spanish PSFs. The data was collected through on-site administration of questionnaires. For each firm, we addressed one questionnaire to the manager and a second questionnaire to be answered by the 'core' employees (i.e. professionals).

Initial contact with the firm was made with the general manager, who identified groups of employees in the firm considered to be 'core' employees (lawyers, accountants, engineers, etc.). The average number of employees in our sample (including both core and non-core employees) was 12.28. Resource limitations hindered us to survey all core employees in each firm, so the number of employees interviewed in each firm was fixed to three to allow for an intra-unit variation in proactive behaviour of core employees to be explained by individual-level characteristics. Of the 300 firms invited to participate, in 102 organisations the general manager provided answers to the manager questionnaire (organisation-response rate of 34\%), which included the questions related to HPWS. In small PSFs, the general manager is usually responsible for human resource activities, and is therefore the appropriate respondent to assess the HPWS items (McClean and Collins, 2011). In all of these firms we obtained three employee questionnaires randomly selected from the group of core employees identified by the manager. Thus, a final sample of 102 organisations and 306 employees were used in the analyses; where 10.8 per cent were firms in the law sub-sector, 40.2 per cent were accounting firms, and 49 per cent were engineering firms. In the employee sample, mean organisational tenure was 8.03 years, average age was 36.75 years, 93.8 per cent of the employees had permanent contracts, 
and 52.3 per cent were female. To detect any possible selection and non-respondent bias in the sample, we used the archival analysis procedure (Rogelberg and Stanton, 2007: 199), examining whether group means for size and performance (ROA and ROE) significantly differed between respondent and non-respondent firms. The results of this analysis $(\mathrm{t}=1.17$, sig. $=0.24$ for $\mathrm{ROA}, \mathrm{t}=0.97$, sig. $=0.34$ for $\mathrm{ROE}, \mathrm{t}=0.0 .54$, sig. $=0.59$ for firm size) reveal no significant differences between the two groups of firms. Similarly, we compared differences in firm size between the population of all firms and those in the sample. The results of the $\mathrm{t}$-test $(\mathrm{t}=0.26$, sig. $=0.79$ for $\mathrm{ROA}, \mathrm{t}=0.18$ sig. $=0.86$ for $\mathrm{ROE}$, $\mathrm{t}=1.28$, sig. $=0.20$ for firm size) showed that our sample of PSFs does not significantly differ from the population of PSFs in terms of size and performance (Short et al., 2002).

\section{Measures}

The measure of HPWS was included in the manager questionnaire. The measures of proactive behaviour, RBSE, and FRO were part of the employee questionnaire. Given that the components of HPWS in PSFs may differ from those used in other more general contexts (Fu, 2013), prior to administering the questionnaire we held personal interviews with five PSF managers to discuss the specific HPWS items included in an initial version. Managers were asked to work through the HPWS item pool and indicate any items that, from their experience, were inappropriate or inapplicable in the sector, ambiguous, or couched in academic language. We also contacted the employees working in the five PSFs whose managers participated in the pre-test to analyse whether the scales included in the employee questionnaire could be easily understood by the employees and made sense in the PSF context. All the scales are shown in the Appendix and Table 1 reports the pattern of correlations among the variables. 
HPWS practices were assessed using Gardner et al.'s (2011) scale. This scale describes HPWS as comprising a set of practices designed to increase the employees' abilities, motivation and opportunity to participate. Attending to the conclusions of the pre-test interviews, several items from Gardner et al.'s (2011) original scale were removed, which left nine items that could be considered representative of the HPWS used in this sector in Spain. For instance, the managers suggested eliminating the item from the original scale referring to the use of reasonable and fair employee complaint processes, given the small size of the PSFs and the use of informal communication channels between managers and employees.

Items in our questionnaire were measured on a scale ranging from 1 to 7 , with anchors varying according to the question. We performed a confirmatory factor analysis (CFA) to test whether the proposed dimensionality of the HPWS corresponded to Gardner et al.'s (2011) original scale. The results of the CFA indicated that the HPWS items significantly loaded on the categories of skill-enhancing, motivation-enhancing and opportunity-enhancing HR practices, as proposed by these authors $\left(\chi_{\mathrm{SB}}^{2}=15.57\right.$; d.f. $=24$; $\mathrm{p}=0.90 ; \mathrm{BBNNFI}=1.00 ; \mathrm{CFI}=1.00 ; \mathrm{RMSEA}=0.00 ; \mathrm{NC}=0.65)$. The Cronbach's alpha coefficient for the full set of items was 0.72. A second-order factor model (in which the second-order factor represents the HPWS construct) was also estimated, with the same fit to the data and degrees of freedom as the CFA. ${ }^{2}$ The loadings of the three subscales were all high and statistically significant, $(0.995,0.695$ and 0.895 for skill-enhancing, motivation-enhancing, and opportunity-enhancing HR, respectively). This result suggests that a single HPWS factor largely explains the correlations between the three subscales

\footnotetext{
${ }^{2}$ The CFA (with three first-order factors) and the single second-order factor model are equivalent models, since they reproduce the same covariance matrix and mean vectors, but using different parameterisations (Bentler and Satorra, 2010).
} 
and provides justification for the use of an aggregated HPWS measure. The existence of a single HPWS factor is also in accordance with prior studies (e.g. Takeuchi et al., 2007). Attending to these results, we combined the full set of HPWS items into three sub-system scores (skill, motivation and opportunity-enhancing HR practices) and then combined these in one aggregate HPWS measure (additive index). Becker and Huselid suggested the use of "a unitary index that contains a set (though not always the same set) of theoretically appropriate HRM practices derived from prior work" (1998: 63). Such an approach is consistent with the argument in the literature that it is the system of practices as a whole that constitutes a strategic asset for the organisation; in addition, using a unitary measure has the advantage of model parsimony (Huselid, 1995; Bae and Lawler, 2000; Guthrie, 2001; Batt, 2002). A high score on this measure indicates intensive investment by the firm in HPWS practices.

The pre-test of the employee questionnaire did not identify any questions requiring modification before being answered by the PSF employees. Similar to prior studies (e.g. Ohly and Fritz, 2007; Sonnentag and Spychala, 2012), we used Frese et al.'s (1997) scale of personal initiative to measure proactive behaviour. The scale proposed by these authors is based on self-reported items referring to the participants' concepts of their own proactivity. The Cronbach's alpha coefficient of scale reliability was 0.82 .

RBSE was measured using Parker's (1998) scale. This scale is made up of ten items that ask the employee how confident he or she feels about carrying out a set of tasks, such as analysing a problem to find a solution or representing his or her work area in meetings with managers. It is a 7-point Likert scale, where (1) represents not at all confident and (7), very confident. The Cronbach's alpha coefficient for this scale was 0.94. 
FRO was measured using Ohly and Fritz's (2007) scale, which consists of three items that target the extent to which employees see developing and implementing new ideas at work as their responsibility, and its Cronbach's alpha coefficient was 0.93.

Prior research has demonstrated that some individual variables are related to proactive behaviour, such as employee intrinsic motivation (Grant and Berry, 2011), organisational tenure (Frese and Fay, 2001), and educational level (Parker et al., 2010). We therefore controlled for the effect of these variables on proactive behaviour in our analyses. Intrinsic motivation was measured with six items proposed by Warr et al. (1979). The Cronbach's alpha coefficient for this scale was 0.72. Organisational tenure was measured as a continuous variable, obtained by asking employees how many years they had been employed in the firm. Finally, we measured their educational level by asking for their most recent formal education level attained, based on the scale included in the 2010 ECVT (Quality of Life at Work Survey) conducted by the Spanish Ministry of Employment. In line with prior studies suggesting that certain unobserved firm and sectoral characteristics may affect HPWS at the organisational level (Takeuchi et al., 2007), we also controlled for the size of the firm (measured by the number of employees) and sector by including two sector dummies (legal activities and engineering consultancy) and used accounting, bookkeeping and auditing as a reference group.

Table one here

\section{Data Analysis}


To test the hypotheses we applied multilevel structural equation modelling (MSEM) using MPlus software (Muthén and Muthén, 1998-2012). MSEM allows us to specify multilevel mediation models with cross-level relationships (e..g. a 2-1-1 multilevel design) (Preacher et al., 2010). Maximum likelihood estimator with standard errors and chi-square test statistics robust to non-normality were used in the analysis.

In the model, we specified a direct cross-level effect of HPWS (the Level 2 antecedent) on proactive behaviour (the Level 1 outcome). The cross-level effect of HPWS on the Level 1 mediator variables RBSE and FRO, and the effect of both RBSE and FRO on the outcome variable were also included in the model to account for the indirect effects of HPWS (i.e. mediated by RBSE and FRO) on proactive behaviour. This latter effect was estimated at both individual and firm levels to avoid problems of conflating the effects at the two levels of analysis (Zhang et al., 2009) when 'contextual' effects are present (Bryk and Raudenbush, 2002). Intrinsic motivation, organisational tenure, educational level, firm size and the sector dummy variables were included in the model as control variables. The path representation of the multilevel mediation model is shown in Figure 1, in which the variable control variables represents the set of five control variables of the model.

Figure one here

\section{RESULTS}


Before estimating the MSEM model in Figure 1, we computed the within- and between-group variance for the proactive behaviour, RBSE and FRO. Both the withinand between-group variance of the three variables were statistically significant. The ratio of between-group to total variance provided an intra-class correlation coefficient (ICC1) (LeBreton and Senter, 2008) of 0.20, 0.18 and 0.19 for proactive behaviour, RBSE and FRO, respectively. This result suggested that it was appropriate to examine the influence of HPWS (the Level 2 predictor) in explaining the variation of proactive behaviour, RBSE and FRO across firms.

Table 2 shows the estimates for the model represented in Figure 1. The chi-square goodness-of-fit test statistic $\left(\chi^{2}=11.35\right.$, d.f. $=12, p$-value $\left.=0.50\right)$ indicated that the model had a good fit to the data. The table shows that HPWS were positively associated with RBSE, with a statistically significant regression coefficient of $0.235(\mathrm{p}<.001)$; the effect of RBSE on proactive behaviour was also significant $(0.807 ; \mathrm{p}<.05)$. The indirect effect of HPWS on proactive behaviour through this mediator variable was significant $(0.167$; $p<0.05)$ and the direct effect of HPWS on proactive behaviour $(-0.088)$ was not statistically significant. Taken together, these findings suggest that RBSE fully mediates the relationship between HPWS and proactive behaviour, a result that provides support for Hypothesis 1.

Regarding the mediating effect of FRO in the HPWS-proactive behaviour relationship, we found that neither the influence of FRO on proactive behaviour $(-0.272)$, nor the effect of HPWS on FRO (0.084) was statistically significant. These results therefore do not support the hypothesis of the mediational effect of FRO on proactive behaviour (Hypothesis 2). 
Finally, Table 2 also shows the influence of the control variables on the variation of proactive behaviour. We found that intrinsic motivation had a significant positive influence on the employees' proactive behaviour $(0.311 ; \mathrm{p}<0.01)$, but the influence of the other control variables was not significant.

Table two here

\section{Supplemental Analysis}

To further examine the relationships between HPWS, proactive behaviour and the mediator variables RBSE and FRO, as separate measures we consider the scores of the skill-enhancing, motivation-enhancing and opportunity-enhancing dimensions of HPWS proposed by Gardner et al. (2011). The multilevel mediational model in Figure 1 was reestimated using the three dimensions of HPWS instead of the unitary index. Results of the disaggregated analyses (not shown in the paper due to space restrictions) indicate that none of the three dimensions of HPWS presented a significant influence on either proactive behaviour or RBSE and FRO. ${ }^{3}$ These results provide support for using the complete set of HR practices that make up the HPWS when analysing the influence on proactive behaviour.

\footnotetext{
${ }^{3}$ Only the empowerment-enhancing HR practices presented a significant positive influence on RBSE $(0.11$, $\mathrm{p}<0.1)$ and FRO $(0.16, \mathrm{p}<0.1)$, both at $10 \%$ significance level.
} 


\section{DISCUSSION}

In this paper we proposed and tested a multilevel model on proactive behaviour and analysed the mediating mechanisms that explain the influence of HPWS on proactive behaviour. We found that for our sample of PSFs there is significant variance in employees' proactive behaviour both within and between firms. After controlling for the influence of a set of individual and contextual variables, our results indicate that the effect of HPWS on proactive behaviour is mediated by employee RBSE, confirming Hypothesis 1. However, in the case of FRO, it does not mediate the HPWS-proactive behaviour relationship; Hypothesis 2 was therefore not supported. These results have several implications for theory and research that we summarise below.

\section{Scholarly implications}

One of the results of this study concerns the influence of a set of HR practices (HPWS) on proactive behaviour. HPWS shape the work context (Johns, 2006; Van De Voorde and Beijer, 2015) and can be viewed as a relevant tool to promote proactivity among the workforce. For our sample of PSFs, we demonstrated that HWPS significantly influence workforce proactivity. Several scholars recommend adopting a broad definition of HR practices to explain employee proactive behaviours. For instance, Unsworth and Parker (2003: 189) argue that changing one HR factor alone (such as selecting individuals with the appropriate KSAs) will not encourage proactivity if other factors (such as a supportive working environment) are not in place. These authors recommend adopting an integrated strategy to enhance proactivity, incorporating elements of recruitment, selection, training, and work design. Our definition of HPWS and the index used to measure HPWS practices responds to the need to adopt an integrated strategy for promoting proactive behaviours. In fact, our supplementary analyses showed that none of 
the HPWS domains on its own significantly affects employee proactive behaviour. It is the bundle of HPWS practices that determines employees' proactive behaviour rather than the influence of a set of isolated practices. The synergy among the HPWS dimensions is related to the idea of internal fit in the HRM literature, according to which the impact of one HR domain on employee performance depends on the presence and effectiveness of other HR domains (Delery and Shaw, 2001; Jiang et al., 2012b; Chang, 2015).

Our results have some implications for the mediation mechanisms through which HPWS affect proactive behaviour, a question that with some exceptions (Parker et al., 2006; Den Hartog and Belschak, 2012; Sonnentag and Spychala, 2012) has attracted less academic interest. By analysing these intermediate variables scholars can gain a deeper understanding of the relationship between HR practices and proactive behaviour. Our results support the expected indirect effect of HPWS on proactive behaviour through RBSE, providing support for the theoretical framework developed by Parker (2000) and Parker et al. (2006), which suggests that contextual causes of proactive behaviour may have an effect on proactivity via more proximal variables related to employees' cognitivemotivational states. Our analyses reveal that HPWS enhance employee RBSE, which in turn has an effect on proactive behaviour. That is, although abilities and skills might be relevant to engagement in proactive behaviours, it is particularly important that employees are also convinced that they can successfully achieve their goals (Sonnentag and Spychala, 2012). However, our results did not corroborate the mediating role of FRO in the relationship between HPWS and proactive behaviour. This may be due to the type of organisations analysed in our research. The nature of work in PSFs entails per se a FRO on the part of employees, since they have discretion to diagnose and solve client problems through different paths (Malhotra and Morrison, 2009). The lower variability of FRO among professionals may explain, for instance, why HPWS do not impact FRO. 
In sum, in our sample of companies the confidence that employees are able to perform a wide set of tasks (RBSE) is more relevant than their beliefs about what their roles are in the firm (FRO) in explaining the effectiveness of HPWS to foster proactive behaviours. This highlights the relevance of the can do motivation to be proactive rather than the reason to motivation, in line with Parker et al.'s (2010) study. Because proactive behaviours entail some psychological risks for employees (e.g. resistance or scepticism from colleagues and managers), they need to be confident they can initiate proactive actions to overcome challenges and obstacles (Parker et al., 2010).

There are some noteworthy conclusions about the significant influence of one of the employee-related control variables on proactive behaviour. Specifically, our study found a significant relationship between employee intrinsic motivation and proactive behaviour, thus corroboratating prior evidence for the relevance of motivational factors to proactivity (e.g. Grant and Berry, 2011). That is, when work is interesting, engaging or satisfying, an employee will be more likely to behave proactively because such behaviour helps to further improve the work situation. This finding confirms the propositions of emotion theories, which posit that intrinsic motivation enhances positive affect in employees and this creates energy for sustaining effort, encouraging employees to persist with challenging and unfamiliar tasks (Grant and Berry, 2011; Sonnentag, 2003).

\section{Implications for practice}

Our results also have implications for management practice. Because many studies have demonstrated that proactive behaviour benefits both individuals and the organisation, managers might want to promote proactivity among their employees. Our findings have implications for organisations' choice of human resource management 
activities to increase employee proactivity. First, our study demonstrates that it is the joint effect of all the HPWS practices on proactivity and RBSE that matters, rather than the individual effect of each HPWS component. Therefore, managers wanting to increase their employees' proactivity should coherently implement the whole set of HPWS practices aimed at increasing employees' skills, motivation and opportunities to participate in the firm.

In addition, our analyses show that RBSE is the variable that explains why HPWS influence proactive behaviour. Therefore, to promote proactive behaviour in the firm through HR practices, it seems advisable for managers to focus on enhancing employee RBSE by, for instance, enhancing workplace communication (Parker, 1998) or reducing situational constraints (i.e. situations that prevent employees from translating ability and effort into high levels of job performance) (Sonnentag and Spychala, 2012)

Finally, we also observed that employees' intrinsic motivation has a direct effect on proactive behaviours. Therefore, in those organisations where proactivity is required among the workforce, managers should pay attention to iniciatives that help increase their employees' motivation (Jiang et al., 2012a).

\section{Limitations and future research}

Some limitations of this study should be noted. As our sample is restricted to PSFs, the generalisability of our results to other types of organisations might be limited. Research on PSFs shows similarities in their organisation and management, and distinctiveness from other types of organisation (Malhotra and Morris, 2009). The nature of work in this type of organisation could make it easier to enhance employees' 
proactivity through HR interventions. In other contexts, HR practices may have a different impact on employee proactivity and other mediators may explain this relationship. For these reasons, we consider there is a need for future replication and extension of this research to other industrial contexts. Similarly, since we restrict our empirical analysis to the core employees, our results cannot be generalised to the entire workforce. Nevertheless, we believe that in PSFs the selected core employees merit a detailed analysis that would be masked if core and non-core employees were analysed jointly. An additional limitation is that we did not collect information about the total number of core employees in each PSF, thus precluding the analysis of the representativeness of the three core employees selected per firm.

In addition, our independent variable (HPWS) was measured through managers opinions about the nature of HR practices used in the firm. However, HR practices as designed by managers do not always correspond to employees' perceptions of such practices (Nishii and Wright, 2008). Future studies should also measure HR practices based on employees' perceptions in order to analyse the extent to which employees experience what management intends in terms of HR practices, and what effect these employees' perceptions have on proactive behaviour.

\section{Conclusion}

In sum, our study aims to contribute to the empirical evidence about the influence of context on employee behaviour. We demonstrate that HPWS have a cross-level influence on employee proactive behaviour through employee RBSE. The main implication for managers that try to increase the proactivity of the firm's workforce is to 
implement a set of integrated high performance HR practices and to invest in activities that promote the RBSE of the employees. 


\section{REFERENCES}

Arefin, M. S., Arif, I. and Raquib, M. (2015). 'High-performance work systems and proactive behavior: The mediating role of psychological empowerment'. International Journal of Business and Management, 10: 132-140.

Axtell, C. M. and Parker, S. K. (2003). 'Promoting role breadth self-efficacy through involvement, work redesign and training'. Human Relations, 56: 112-131.

Axtell, C.M., Holman, D.J., Unsworth, K.L., Wall, T.D., Waterson, P.E. and Hurrington, E. (2000). 'Shopfloor innovation: Facilitating the suggestion and implementation of ideas'. Journal of Occupational and Organizational Psychology, 73: 265-285.

Bae, J. and Lawler, J.J. (2000). 'Organizational and HRM strategies in Korea: Impact on firm performance in an emerging economy'. Academy of Management Journal, 43: 502-517.

Bailey, T., Berg, P. and Sandy, C. (2001). 'The effect of high performance work practices on employee earnings in the steel, apparel, and medical electronics and imaging industries'. Industrial and Labor Relations Review, 54: 525-543.

Bandura, A. (1986). Social foundations of thought and action: A social-cognitive view. Englewood Cliffs, NJ: Prentice Hall.

Batistič, S., Černe, M., Kaše, R. and Zupic, I. (2016). 'The role of organizational context in fostering employee proactive behavior: The interplay between HR system configurations and relational climates'. European Management Journal, 34: 579588. 
Batt, R. (2002). 'Managing customer services: Human resource practices, quit rates, and sales growth'. Academy of Management Journal, 45: 587-597.

Becker, B. E. and Huselid, M. A. (1998). 'High performance work systems and firm performance: A synthesis of research and mimagerial implications'. In G. R. Ferris (Ed.), Research in Personnel and Human Resources Management, Greenwich, GT: JAI Press.

Belschak, F.D. and Den Hartog, D.N. (2010). 'Pro-self, prosocial, and pro-organizational foci of proactive behaviour: Differential antecedents and consequences'. Journal of Occupational and Organizational Psychology, 83: 475-498.

Bentler, P. M. and Satorra, A. (2010). 'Testing model nesting and equivalence'. Psychological Methods, 15: 111.

Blau, P.M. (1964). Exchange and power in social life. New York: Wiley.

Bryk, A.S. and Raudenbush, S.W. (2002). Hierarchical Linear Models: Applications and Data Analysis Methods. Newbury Park, CA: Sage.

Caesens, G., Marique, G., Hanin, D. and Stinglhamber, F. (2016). 'The relationship between perceived organizational support and proactive behavior directed towards the organization". European Journal of Work \& Organizational Psychology, 25: 398-411.

Campbell, D.J. (2000). 'The proactive employee: Managing workplace initiative'. Academy of Management Executive, 14: 52-66. 
Chang, Y. Y. (2015). 'A multilevel examination of high performance work systems and unit-level organisational ambidexterity’. Human Resource Management Journal, 25: 79-101.

Conger, J.A. and Kanungo, R.N. (1998). 'The empowerment process: Integrating theory and practice'. Academy of Management Review, 13: 471-482.

Crant, J.M. (2000). 'Proactive behavior in organizations'. Journal of Management, 26: $435-462$.

Crawshaw, J.R., van Dick, R. and Brodbeck, F.C. (2012). 'Opportunity, fair process and relationship value: career development as a driver of proactive work behavior'. Human Resource Management Journal, 22: 4-20.

Delery, J..E. and Shaw, J.D. (2001). 'The strategic management of people in work organizations: Review, synthesis, and extension. In G.R. Ferris (Ed.), Research in personnel and human resource management. Stamford, CT: JAI Press.

Den Hartog, D.N. and Belschak, F.D. (2012). 'When does transformational leadership enhance employee proactive behavior? The role of autonomy and role breadth self-efficacy', Journal of Applied Psychology, 97: 194-202.

Dyer, L. and Shafer, R.A. (2002). 'Dynamic organizations: Achieving marketplace and organizational agility with people'. In Peterson, R. and Mannix, E (eds), Understanding the Dynamic Organization, Mahwah, NJ: Lawrence Erlbaum Associates.

Eisenberger, R., Huntington, R., Hutchinson, S. and Sowa, D. (1986). 'Perceived organizational support'. Journal of Applied Psychology, 71: 500-507. 
Elliot, A. J. and Devine, P. G. (1994). 'On the motivational nature of cognitive dissonance: Dissonance as psychological discomfort'. Journal of Personality and Social Psychology, 67: 382-394.

Frese, M. and Fay, D. (2001). 'Personal initiative: An active performance concept for work in the 21st century'. In Staw, B.M. and Sutton, R.I. (Eds.), Research in Organizational Behavior, Amsterdam: Elsevier Science.

Frese, M., Fay, D., Hilburger, T., Leng, K. and Tag, A. (1997). 'The concept of personal initiative: Operationalization, reliability and validity in two German samples'. Journal of Organizational and Occupational Psychology, 70: 139-161.

Frese, M., Kring, W., Soose, A. and Zempel, J. (1996). 'PI at work: Differences between East and West Germany'. Academy of Management Journal, 39: 37-63.

Fu, N. (2013). 'Exploring the impact of High Performance Work Systems in professional service firms: A practices-resources-uses performance approach'. Consulting Psychology Journal: Practice and Research, 65, 240-257.

Gardner, T.M., Wright, P.M. and Moynihan, L.M. (2011). 'The impact of motivation, empowerment, and skill-enhancing practices on aggregate voluntary turnover: The mediating effect of collective affective commitment'. Personnel Psychology, 64: $315-350$.

Grant, A.M. and Berry, J.W. (2011). 'The necessity of others is the mother of invention: Intrinsic and prosocial motivations, perspective taking, and creativity'. Academy of Management Journal, 54: 73-96. 
Gratton, L., Hope-Hailey, V., Stiles, P. and Truss, C. (1999). 'Linking individual performance to business strategy: the people process model'. Human Resource Management, 38: 1, 17-31.

Guest, D. E. and Conway, N. (2002). 'Communicating the psychological contract: an employer perspective'. Human Resource Management Journal, 12: 22-38.

Guthrie, J.P. (2001). 'High-Involvement work practices, turnover, and productivity: Evidence from New Zealand'. Academy of Management Journal, 44: 180-190.

Hermann, D. and Felfe, J. (2014). 'Effects of leadership style, creativity technique and personal initiative on employee creativity'. British Journal of Management, 25: 209-227.

Hitt, M. A., Beamish, P. W., Jackson, S. E. and Mathieu, J. E. (2007). 'Building theoretical and empirical bridges across levels: Multilevel research in management'. Academy of Management Journal, 50: 1385-1399.

Hitt, M.A., Bierman, L., Uhlenbruck, K. and Shimizu, K. (2006). The importance of resources in the internationalization of professional service firms: The good, the bad, and the ugly. Academy of Management Journal, 49: 1137-1157.

House, R., Rousseau, D. M. and Thomas-Hunt, M. (1995). 'The meso paradigm: A framework for the integration of micro and macro organizational behavior'. In L. L. Cummings \& B. M. Staw (Eds.), Research in organizational behavior, vol. 17: 71-114. Greenwich, CT: JAI Press. 
Howell, J.M. and Boies, K. (2004). 'Champions of technological innovation: The influence of contextual knowledge, role orientation, idea generation, and idea promotion on champion emergence'. The Leadership Quarterly, 15: 123-143.

Huselid, M.A. (1995). 'The impact of human resource management practices on turnover, productivity, and corporate financial performance'. Academy of Management Journal, 38: 635-672.

Hwang, P. C., Han, M. C. and Chiu, S. F. (2015). 'Role breadth self-efficacy and foci of proactive behavior: Moderating role of collective, relational, and individual selfconcept'. The Journal of psychology, 149: 846-865.

Ichniowski, C., Shaw, K. and Prennushi, G. (1997). 'The effects of human resource management practices on productivity: A study of steel finishing lines", The American Economic Review, 87: 291-313.

Jiang, K., Lepak, D.P., Han, K., Hong, Y., Kim, A. and Winkler, A.L. (2012b). 'Clarifying the construct of human resource systems: Relating human resource management to employee performance'. Human Resource Management Review, 22: 73-85.

Jiang, K., Lepak, D.P., Hu, J. and Baer, J.C. (2012a). 'How does human resource management influence organizational outcomes? A meta-analytic investigation of mediating mechanisms'. Academy of Management Journal, 55: 1264-1294.

Johns, G. (1991). 'Substantive and methodological constraints on behavior and attitudes in organizational research'. Organizational Behavior and Human Decision Processes, 49: 80-104. 
Johns, G. (2006). 'The essential impact of context on organizational behavior'. Academy of Management Review, 31: 386-408.'

Kickul, J. and Gundry, L.K. (2002). 'Prospecting for strategic advantage: The proactive entrepreneurial personality and small firm innovation'. Journal of Small Business Management, 40: 85-97.

Kipping, M. and Kirkpatrick, I. (2013). 'Alternative pathways of change in professional services firms: The case of management consulting'. Journal of Management Studies, 50: 777-807.

Leary, M.R. and Kowalski, R.M. (1990). 'Impression management: A literature review and two-component model'. Psychological Bulletin, 107: 34-47.

LeBreton, J.M. and Senter, J.L. (2008). 'Answers to 20 questions about interrater reliability and interrater agreement'. Organizational Research Methods, 11: 815852.

Locke, E. A. and Latham, G. P. (1990). A theory of goal setting and task performance. Englewood Cliffs, NJ: Prentice-Hall, Inc.

Lowendahl, B.R. (2005). Strategic management of professional service firms. Copenhage: Copenhagen Business School Press.

MacDuffie, J. (1995). 'Human resource bundles and manufacturing performance: Organizational logic and flexible production systems in the world auto industry". Industrial and Labor Relations Review, 48: 197-221. 
Maden, C. (2015). 'Linking high involvement human resource practices to employee proactivity'. Personnel Review, 44: 720-738.

Malhotra, N. and Morris, T. (2009). 'Heterogeneity in professional service firms'. Journal of Management Studies, 46: 895-922.

Martin, S. L., Liao, H. and Campbell, E. M. (2013). 'Directive versus empowering leadership: A field experiment comparing impacts on task proficiency and proactivity'. Academy of Management Journal, 56: 1372-1395.

McClean, E. and Collins, C. J. (2011). 'High commitment HR practices, employee effort, and firm performance: Investigating the effects of HR practices across employee groups within professional services firms'. Human Resource Management, 50: 341-363.

Morrison, E. W. (1994). 'Role definitions and organizational citizenship behavior: The importance of the employee's perspective'. Academy of Management Journal, 37: $1543-1567$.

Muthén, L. K. and Muthén, B. O. (1998-2012). Mplus User's Guide. Seventh Edition. Los Angeles, CA: Muthén and Muthén.

Neale, M. and Griffin, M. A. (2006). 'A model of self-held work roles and role transitions'. Human Performance, 19: 23-41.

Nishii, L. H. and Wright, P. M. (2008). 'Variability within organizations: implications for strategic human resources management'. In Smith, D. B. (ed.), The People Make the Place: Dynamic Linkages between Individuals and Organizations. New York: Lawrence Erlbaum Associates 
Ohly, S. and Fritz, C. (2007). 'Challenging the status quo: What motivates proactive behaviour?' Journal of Occupational and Organizational Psychology, 80: 623629.

Ohly, S., Sonnentag, S. and Pluntke, F. (2006). 'Routinization, work characteristics and their relationships with creative and proactive behaviors'. Journal of Organizational Behavior, 27: 257-279.

Parker, S.K. (1998). 'Role breadth self-efficacy: Relationship with work enrichment and other organizational practices'. Journal of Applied Psychology, 83: 835-852.

Parker, S.K. (2000). 'From passive to proactive motivation: The importance of flexible role orientation and role breadth self-efficacy'. Applied Psychology: An International Review, 49: 447-469.

Parker, S.K. (2007). '«That is my job»: How employees’ role orientation affects their job performance'. Human Relations, 60: 403-434.

Parker, S.K., Bindl, U.K. and Strauss, K. (2010). 'Making things happen: A model of proactive motivation'. Journal of Management, 36: 827-856.

Parker, S.K., Wall, T.D. and Jackson, P.R. (1997). “«That's not my job»: Developing flexible employee work orientations'. Academy of Management Journal, 40: 899929.

Parker, S.K., Williams, H.M. and Turner, N. (2006). 'Modeling the antecedents of proactive behavior at work'. Journal of Applied Psychology, 91: 636-652. 
Preacher, K. J., Zyphur, M. J. and Zhang, Z. (2010). 'A general multilevel SEM framework for assessing multilevel mediation'. Psychological Methods, 15: 209233.

Richter, A., Dickmann, M. and Graubner, M. (2008). 'Patterns of human resource management in consulting firms'. Personnel Review, 37: 184-202.

Rogelberg, S. G. and Stanton, J. M. (2007). 'Introduction understanding and dealing with organizational survey nonresponse'. Organizational Research Methods, 10: 195209.

Seibert, S.E., Kraimer, M.L. and Crant, J.N. (2001). 'What do proactive people do? A longitudinal model linking proactive personality and career success'. Personnel Psychology, 54: 845-874.

Shin, Y. and Kim, M. J. (2015). 'Antecedents and mediating mechanisms of proactive behavior: Application of the theory of planned behavior'. Asia Pacific Journal of Management, 32:, 289-310.

Short, J. C., Ketchen, D. J. and Palmer, T. B. (2002). 'The role of sampling in strategic management research on performance: A two-study analysis'. Journal of Management, 28: 363-385.

Shukla, A. and Singh, S. (2014). 'Employee involvement and flexible role orientation: A moderated mediated model'. The Indian Journal of Industrial Relations, 49: 663676. 
Snape. E. and Redman, T. (2010). 'HRM practices, organizational citizenship behaviour, and performance: A multi-level analysis'. Journal of Management Studies, 47: 1219-1247.

Sonnentag, S. (2003). 'Recovery, work engagement, and proactive behavior: A new look at the interface between nonwork and work'. Journal of Applied Psychology, 88: 518-528.

Sonnentag, S. and Spychala, A. (2012). 'Job control and job stressors as predictors of proactive work behavior: Is role breadth self-efficacy the link?' Human Performance, 25: 412-431.

Speier, C. and Frese, M. (1997). 'Generalized self-efficacy as a mediator and moderator between control and complexity at work and personal initiative: A longitudinal study in East Germany'. Human Performance, 10: 171-192.

Strauss, K., Griffin, M.A. and Rafferty, A.E. (2009). 'Proactivity directed toward the team and organization: The role of leadership, commitment and role-breadth selfefficacy’. British Journal of Management, 20: 279-291.

Subramony, M. (2009). 'A meta-analytic investigation of the relationship between HRM bundles and firm performance'. Human Resource Management, 48: 745-768.

Takeuchi, R., Lepak, D.P., Wang, H. and Takeuchi, K. (2007). 'An empirical examination of the mechanisms mediating between high performance work systems and the performance of Japanese organizations'. Journal of Applied Psychology, 92: 1069-1083. 
Thomas, J. P., Whitman, D. S. and Viswesvaran, C. (2010). 'Employee proactivity in organizations: A comparative meta-analysis of emergent proactive constructs'. Journal of Occupational and Organizational Psychology, 83: 275-300.

Thomas, J. P., Whitman, D. S. and Viswesvaran, C. (2010). Employee proactivity in organizations: A comparative meta-analysis of emergent proactive constructs'. Journal of Occupational and Organizational Psychology, 83: 275-300.

Unsworth, K.L. and Parker, S.K. (2003). 'Proactivity and innovation: Promoting a new workforce for the new workplace'. In Holman, D., Wall, T.D., Clegg, C.W., Sparrow, P. and Howard, A. (eds), The New Workplace. A Guide to the Human Impact of Modern Working Practices, West Sussex: John Wiley and Sons, Ltd.

Van De Voorde, K. and Beijer, S. (2015). 'The role of employee HR attributions in the relationship between high performance work systems and employee outcomes'. Human Resource Management Journal, 25: 62-78.

Warr, P.B., Cook, J.D. and Wall, T.D. (1979). 'Scales for the measurement of some work attitudes and aspects of psychological well-being'. Journal of Occupational Psychology, 52: 129-148.

Way, S. A. (2002). 'High performance work systems and intermediate indicators of firm performance within the U.S. small business sector'. Journal of Management, 28: $765-85$.

Wood, R. and Bandura, A. (1989). 'Social cognitive theory and organizational management'. Academy of Management Review, 14: 361-384. 
Zhang, Z., Zyphur, M.J. and Preacher, K.J. (2009). 'Testing multilevel mediation using hierarchical linear models: Problems and solutions'. Organizational Research Methods, 12: 695-719. 
FIGURE 1

Theoretical model

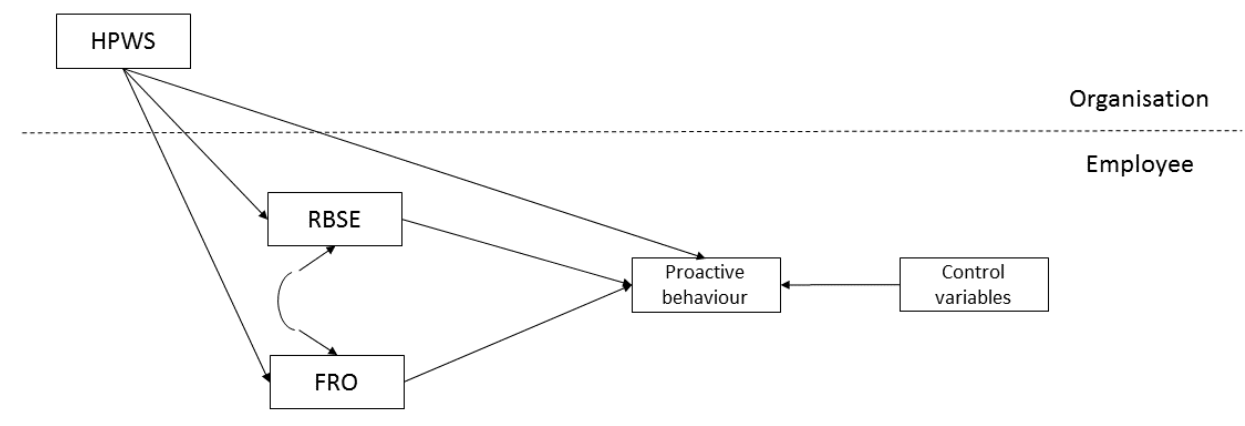


TABLE 1

Descriptive Statistics and Correlations

\begin{tabular}{|c|c|c|c|c|c|c|c|}
\hline Variable & Means & s.d. & 1 & 2 & 3 & 4 & 5 \\
\hline $\begin{array}{l}\text { 1.Proactive } \\
\text { behaviour }\end{array}$ & 5.54 & 0.82 & & & & & \\
\hline $\begin{array}{l}\text { 2. Flexible role } \\
\text { orientation }\end{array}$ & 4.62 & 1.23 & $.45 * *$ & & & & \\
\hline $\begin{array}{l}\text { 3. Role breadth } \\
\text { self-efficacy }\end{array}$ & 5.25 & 1.10 & $.54 * *$ & $.55^{*}$ & & & \\
\hline $\begin{array}{l}\text { 4. Intrinsic } \\
\text { motivation }\end{array}$ & 5.82 & 0.80 & $.31 * *$ & $.22 * *$ & $.21 * *$ & & \\
\hline $\begin{array}{l}\text { 5. Organisational } \\
\text { tenure }\end{array}$ & 8.03 & 5.15 & .09 & .06 & .07 & $-.11^{*}$ & \\
\hline $\begin{array}{l}\text { 6. Educational } \\
\text { level }\end{array}$ & 7.15 & 2.70 & $.20 * *$ & $.20 * *$ & $.26^{* *}$ & .05 & -.05 \\
\hline$+\mathrm{p}<.10$ & & & & & & & \\
\hline$* \mathrm{p}<.05$ & & & & & & & \\
\hline$* * \mathrm{p}<.01$ & & & & & & & \\
\hline
\end{tabular}


TABLE 2

Estimates of multilevel mediation model for employees' proactive behaviour

\begin{tabular}{lc}
\hline & Estimates (s.e.) \\
\hline & \\
Organizational level (Level 2): & \\
Direct effects: & $-0.088(.097)$ \\
\hline HPWS $\rightarrow$ Proactive behaviour & $0.235(.072)^{* * *}$ \\
HPWS $\rightarrow$ RBSE & $0.084(.133)$ \\
HPWS $\rightarrow$ FRO & $0.807(.382)^{* *}$ \\
RBSE $\rightarrow$ Proactive behaviour & $-0.272(.267)$ \\
FRO $\rightarrow$ Proactive behaviour & $0.095(.613)$ \\
Intrinsic motivation $\rightarrow$ Proactive behaviour & $0.020(.131)$ \\
Organisational tenure $\rightarrow$ Proactive behaviour & $0.085(.424)$ \\
Educational level $\rightarrow$ Proactive behaviour & $-0.070(.502)$ \\
Legal activities (dummy) $\rightarrow$ Proactive behaviour & $0.179(.117)$ \\
Engineering consultancy(dummy) $\rightarrow$ Proactive & \\
behaviour & \\
Size (number of employees) $\rightarrow$ Proactive behaviour & $0.002(.005)$ \\
& \\
\hline Indirect effects: & \\
\hline HPWS $\rightarrow$ Proactive behaviour & $0.311(.068)^{* * *}$ \\
Employee level (Level 1$):$ & $0.010(.010)$ \\
Intrinsic motivation $\rightarrow$ Proactive behaviour & \\
Organisational tenure $\rightarrow$ Proactive behaviour & $0.011(.010)$ \\
Educational level $\rightarrow$ Proactive behaviour & \\
\hline RBSE $\rightarrow$ Proactive behaviour & \\
\hline
\end{tabular}

Notes: Unstandardised coefficient estimates. Standard Errors in brackets. ${ }^{*} \mathrm{p}<.10 .{ }^{* *} \mathrm{p}<.05 .{ }^{* * *} \mathrm{p}<.01$ 


\section{APPENDIX}

\section{High Performance Work System scale}

1. How extensive is the employee selection process to fill a position? ( $1=$ not extensive: use of few staffing techniques; $7=$ very extensive: use of many different techniques)

2. On average, how many hours of formal training does an employee receive per year? $(1=0 \mathrm{~h} ; 7=>60 \mathrm{~h})$

3. What is the main purpose of the performance evaluation processes in the firm? $(1=$ employee performance control; $7=$ to determine training needs and contribute to employee development)

4. What percentage of employees in your firm is covered by performance appraisal systems? $(1=10 \%$ of employees or less; $4=40 \%$ of employees; $7=70 \%$ of employees or more)

5. How closely are pay rises, promotions, etc. tied to performance appraisal in this department? $(1=$ not closely; $4=$ moderately; $7=$ very closely)

6. How closely is pay tied to individual performance, in terms of percentage of the salary? $(1=<10 \% ; 2=$ $10 \%-20 \% ; 3=20 \%-30 \% ; 4=30 \%-40 \% ; 5=40 \%-50 \% ; 6=50 \%-60 \%, 7=>60 \%$ )

7. What relevance do formal participation processes such as quality improvement groups, problem solving groups or suggestions systems have in your firm? $(1=$ used sporadically with less than $10 \%$ of employees participating; $7=$ extensive use, with $80 \%$ or more of employees participating)

8. To what extent are formal meeting systems used to inform employees about the firm's situation (e.g. strategy, results, etc.)? (1= used sporadically with less than $10 \%$ of employees participating; $7=$ extensive use, with $80 \%$ or more of employees participating)

9. Employees in this firm communicate with people in other areas to solve problems and meet deadlines $(1=$ completely disagree; $7=$ completely agree)

\section{Proactive behaviour scale}

Indicate your level of agreement or disagreement with the following statements:

$\begin{array}{ccccccc}1 & 2 & 3 & 4 & 5 & 6 & 7 \\ \text { Completely disagree } & & & & & \text { Completely agree }\end{array}$

1. I tackle problems actively.

2. Whenever something goes wrong, I search for a solution immediately.

3. Whenever there is a chance to get actively involved, I take it.

4. I take the initiative immediately even when others don't.

5. I use opportunities quickly in order to attain my goals.

6. Usually I do more than I am asked to do.

7. I am particularly good at carrying out ideas.

\section{Intrinsic motivation scale}

For each question, tick the box that fits how you would describe yourself:

$$
\begin{array}{ccccccc}
1 & 2 & 3 & 4 & 5 & 6 & 7 \\
\text { Completely disagree } & & & & & \text { Completely agree }
\end{array}
$$

1. I feel a sense of personal satisfaction when I do this job well

2. My opinion of myself goes down when I do this job badly

3. I take pride in doing my job as well as I can

4. I feel unhappy when my work is not up to my usual standard

5. I like to look back on the day's work with a sense of a job well done

6. I try to think of ways of doing my job effectively 


\section{Flexible role orientation scale}

Indicate your level of agreement or disagreement with the following statements:

$$
\text { Completely disagree } \quad \begin{array}{llllll}
1 & & & 6 & 7 \\
\text { Completely agree }
\end{array}
$$

1. It is my job to develop new ideas and to test them

2. It is my task to be innovative

3. My job requires the development and implementation of new ideas.

\section{RBSE scale}

How confident would you feel:

$\begin{array}{ccccccc}1 & 2 & 3 & 4 & 5 & 6 & 7 \\ \text { Not at all confident } & & & \text { Very confident }\end{array}$

1. Analysing a long-term problem to find a solution

2. Representing your work area in meetings with senior management

3. Designing new procedures for your work area

4. Making suggestions to management about ways to improve the working of your section

5. Contributing to discussions about the company's strategy

6. Writing a proposal to spend money in your work area

7. Helping to set targets/goals in your work area

8. Contacting people outside the company (e.g. suppliers, customers) to discuss problems

9. Presenting information to a group of colleagues

10. Visiting people from other departments to suggest doing things, differently 